\title{
CHEMICAL ASSESSMENT OF FARMED AND NATURAL FISH
}

Ahmad. A. Hamza"; Ebraheim M. Aman", Yehia. E. Ali" and Nader Y.Moustafa".

"MV.Sc. (2003) Food hygiene. Fac. Of Vet Med., Kafrelsheikh Univ., Egypt

"* Food control Dep. Fac. Of Vet Med., Kafrelsheikh Univ., Egypt

\begin{abstract}
160 random samples of natural Tilapia nilotica (NT), farmed Tilapia nilotica (FT), natural Mugil cephalus (NM) and farmed Mugil cephalus (FM) (40 of each) were collected from eight fish farms and Alborolos lake in Kafr El-sheikh governorate through 12 months. The collected samples were subjected to chemical examinations to evaluate the effect of rearing conditions and fish types on nutritional value and quality of the examined fish. The study revealed that the farming rearing conditions leads to a significant higher fat and protein percent in farmed fish than natural fish while the Mugil cephalus species were higher than tilapia nilotica in fat and protein percent.
\end{abstract}

\section{INTRODUCTION}

Fish either natural or farmed are gained an increase importance as a healthy food, because numerous species have been identified as rich in therapeutically important polyunsaturated fatty acids, easily digestible proteins, vitamins, and various other micro nutrients. Concurrently, important changes in pattern of food consumption are occurring including preference for safe and minimally processed foodstuffs. (Campos et al. 2010). 
The quality of fish is a very difficult concept to explain due to different varieties of factors that must be considered. Population, fish species, spawning period, nutrition, post-harvest handling, and storage are some of the key factors that will impact the quality of a fish product (Nielsen et al. 2002). Natural and farmed fish are vary in their nutrients contents, sensorial, microbiological and chemical properties. (Grigorakis et al., 2003).

Proximate composition of fish involves the determination of moisture, lipid, protein and ash content. The proximate composition of fish is affected by a diversity of factors such as: size, sexual maturation, temperature, salinity, exercise, ration, time and feeding frequency, starvation, type and amount of dietary ingredients (FAO, 2007).

Kafr El-Sheikh governorate becomes the largest areas of fish production in Egypt. The main fish species cultured in Kafr El-Sheikh are Tilapia nilotica and Mugil cephalus, which represents an important part of the naturally caught fish. Therefore, the present study planned to assess the chemical quality of both natural and farmed Tilapia nilotica and Mugil cephalus through determination of proximate composition of the examined fish samples.

\section{MATERIALS AND METHODS}

\section{Collection of samples:}

A total of 160 random samples of Tilapia Nilotica and Mugil cephalus 40 of each were collected from eight fish farms(10 samples from each farm), and 40 of each were collected from Alborolos lake, and the run off channels leading to it in Kafr El-Sheikh Governorate in 12 months duration. 
The collected samples are packed in a sterile polyethylene bags, and cooled in a box contained crushed ice, then immediately transferred to the laboratory.

\section{Chemical assessment:}

- Determination of moisture content according to (AOAC, 2000).

- Determination of protein content in fish according to $(\boldsymbol{A O} A \boldsymbol{C}, 2000)$.

- Determination of protein content in fish according to $(\boldsymbol{A O A C}, 2000)$.

- Determination of ash in fish samples by ashing.

\section{RESULTS}

Table (1): Statistical analytical results of moisture percent of the examined fish meat.n $=40$.

\begin{tabular}{|c|c|c|c|}
\hline Fish groups & Minimum & Maximum & Mean \pm S.E.M \\
\hline Natural Tilapia Nilotica & 72.2 & 76.2 & $74.14 \pm 0.13 \mathrm{~A}$ \\
\hline Farmed Tilapia Nilotica & 70.9 & 75.4 & $72.91 \pm 0.14 \mathrm{~B}$ \\
\hline Natural Mugil cephalus & 70.5 & 74.2 & $72.12 \pm 0.14 \mathrm{C}$ \\
\hline Farmed Mugil cephalus & 69.5 & 73.3 & $71.20 \pm 0.11 \mathrm{D}$ \\
\hline
\end{tabular}

Means within the same column of different litters are significantly different at $(\mathrm{P}<0.01)$.

S.E.M $=$ Standard error of mean

$\overline{\text { Kafrelsheikh Vet. Med. J. Vol. } 10 \text { No. } 1 \text { (2012) }}$ 
Ahmad. A. Hamza et., al..

Table (2): Statistical analytical results of protein percent of examined fish meat $n=40$

\begin{tabular}{|c||c||c||c||}
\hline Fish type & Minimum & Maximum & Mean \pm S.E.M \\
\hline \hline Natural Tilapia nilotica & 16 & 21 & $18.51 \pm 0.18 \mathrm{C}$ \\
\hline Farmed Tilapia nilotica & 16.2 & 19.3 & $17.91 \pm 0.12 \mathrm{D}$ \\
\cline { 2 - 4 } Natural Mugil cephalus & 17.8 & 23.1 & $20.05 \pm 0.20 \mathrm{~A}$ \\
\hline Farmed Mugil cephalus & 16.3 & 22.8 & $18.9 \pm 0.17 \mathrm{~B}$ \\
\hline \hline
\end{tabular}

Means within the same column of different litters are significantly different at $(\mathrm{P}<0.01)$.

S.E.M $=$ Standard error of mean

Table (3): Statistical analytical results of fat of the examined fish meat. $n=40$

\begin{tabular}{||c||c||c||c||}
\hline Type of samples & Minimum & Maximum & Mean \pm S.E.M \\
\hline \hline Natural Tilapia nilotica & 1.5 & 3.8 & $2.20 \pm 0.09 \mathrm{C}$ \\
\hline \multirow{2}{*}{ Farmed Tilapia nilotica } & 1.8 & 4.1 & $2.98 \pm 0.11 \mathrm{~B}$ \\
\hline Natural Mugil cephalus & 2.5 & 4.5 & $3.25 \pm 0.11 \mathrm{~B}$ \\
\hline Farmed Mugil cephalus & 3.2 & 5.8 & $4.9 \pm 0.12 \mathrm{~A}$ \\
\hline
\end{tabular}

Means within the same column of different litters are significantly different at $(\mathrm{P}<0.01)$.

S.E.M $=$ Standard error of mean

Table (4): Statistical analytical results of ash of the examined fish meat.

\begin{tabular}{|c||c||c||c||}
\hline Fish groups & Minimum & Maximum & Mean \pm S.E.M \\
\hline \hline Natural Tilapia nilotica & 1.1 & 2.91 & $2.21 \pm 0.10 \mathrm{~A}$ \\
\hline Farmed Tilapia nilotica & 0.9 & 2.8 & $1.82 \pm 0.6 \mathrm{~B}$ \\
\hline Natural Mugil cephalus & 1.3 & 3.1 & $2.15 \pm 0.07 \mathrm{~A}$ \\
\hline Farmed Mugil cephalus & 0.9 & 2.1 & $1.46 \pm 0.09 \mathrm{C}$ \\
\hline
\end{tabular}

Means within the same column of different litters are significantly different at $(\mathrm{P}<0.01)$.

S.E.M $=$ Standard error of mean

$\overline{\text { Kafrelsheikh Vet. Med. J. Vol. } 10 \text { No. } 1 \text { (2012) }}$ 


\section{DISCUSSION}

\section{Moisture content:}

Data recorded in Table (1) indicate that, the moisture content (74.14 \& 72.91) observed in natural Tilapia nilotica and farmed $T$ nilotica was higher than that observed $(72.12 \& 71.20)$ in natural $M$ cephalus and farmed Mugil cephalus fish, respectively.

The previous results show that, natural fish samples has a higher moisture content than that of the farmed fish samples while according to fish species the Tilapia nilotica fish samples has a higher moisture content than that of Mugil cephalus.

These results agree with those of Aussanasuwannakul et al. (2010) where they reported that, the natural fish contains higher moisture content than the farmed fish. They explained it by the limited and controlled environmental conditions.

Higher results were recorded by Attouchi and Sadok (2011), who found that, natural fish moisture content is $79.17 \pm 1.01$ while that of farmed fish is $75.10 \pm 1.03$. These results may be attributed to the high dietary fat level in the feed and reduced activity of cultured fish. Additionally, the unlimited access to feed in intensive farming system leads to increased muscle carbohydrates (Kristoffersen et al. 2006).

\section{Protein content:}

The protein content for each fish species varies according to many factors. The value of protein increases with spawning season, maturation, and the high protein diet. The variation in protein source has influenced the organoleptic properties of fresh water fish by changing the color or altering the flavor. (Franceso, 2004).

$\overline{\text { Kafrelsheikh Vet. Med. J. Vol. } 10 \text { No. } 1 \text { (2012) }}$ 
The content of examined fish showed a high levels of protein in natural Mugil cephalus followed by farmed Mugil cephalus and their percent were $20.05 \pm 0.20$ and $18.9 \pm 0.17$, respectively, while the lower protein levels observed in natural Tilapia nilotica and farmed Tilapia nilotica and their percent were $18.51 \pm 0.18$ and $17.91 \pm 0.12$, respectively (Table 2).

As regarding to fish species the previous results shows that Mugil cephalus protein percent is more than Tilapia nilotica, while as regarding to rearing conditions the natural fish protein percent is higher than farmed fish. This differences between Tilapia nilotica and Mugil cephalus may be attributed to that the fish species has a direct influence on the protein content, as protein percent not impacted by diet, but mainly is determined by the species type, genetic characteristics and size. (Morris, 2001.; and Francesco et al. 2004).

Also the higher percent of protein in nature fish may be explained by that natural fish contains lower percent of fat than farmed fish resulting in elevating the percent of protein for naturally living fish.

The previous results agreed with those reported by Grigorakis et al., (2003), Gines et al., (2004) and Attouchi and Sadok (2011).

Protein oxidation in fish meat considered to impact negatively on the muscle texture. An important source of free radicals taking part in this process is Fenton's reaction dependent ferrous ions present in the tissue. That causes significantly increased carbonylation of important structural proteins in fish muscle, mainly actin and myosin and degradation products of those proteins were observed, some of them exhibiting increased carbonylation levels. (Pazos et al.2011). 


\section{Fat content:}

Lipid content of fish flesh, is directly related to the nutrition of the fish. (Grigorakis et al., 2003). On the other hand the lipid content of natural fish, however, cannot be manipulated by the fisherman and will be mainly influenced by the prey type and availability, among other factors. (Haard,1992).

Table (3) and Fig. (9) Cleared that, the higher level of fat observed in farmed Mugil cephalus and natural Mugil cephalus and their level $4.9 \pm 0.12$ and $3.25 \pm 0.11$. While the lower level of fat observed in farmed Tilapia nilotica and natural Tilapia nilotica and their level about $2.98 \pm 0.11$ and $2.2 \pm 0.09$, respectively.

The results agreed with those of Kaushik (2004) where he reported that there is an increase in lipid concentration in muscles of farmed brackish water fish as well as the whole body than natural fish.

Our results indicated that, the farmed fish type of a higher fat content than that of natural fish type. These results attributed to the feeding program of the accessible and well-formulated diets for farmed fish that considered the fat percent of the ration for fish. The increasing level of the fat in the muscle of the fish consequently leads to rapid deterioration of the fish.

In addition, our results indicated that, the Mugil cephalus species posses a higher percent of fat than that of Tilapia nilotica fish species, these results attributed to that Mugil cephalus is considered a fatty fish type while Tilapia nilotica is characterized by lower fat content. Similar results were reported by El-Ebiary and Zaki (2003) and Abdelhamid et al. (2005).

$\overline{\text { Kafrelsheikh Vet. Med. J. Vol. } 10 \text { No. } 1 \text { (2012) }}$ 
The high fat content in the fish causes rapid deterioration and spoilage of the fish with poor quality of the fish meat and the level of the fat in ration of the fish not increased than $8 \%$ for obtaining good quality fish meat. (Borges et al. 2009).

The importance of nutrition in farmed fish is enormous and equips fish farmers with a powerful tool to design products that can not only affect human health positively, but also generate products preferred by consumers.

\subsubsection{Ash:}

The level of ash differe significantly among different examined fish. The higher level observed in natural Tilapia nilotica and natural Mugil cephalus and their mean value were 2.21 \pm 0.10 and $2.15 \pm 0.07$ respectively and the lower ash level observed in farmed Tilapia nilotica and farmed Mugil cephalus and the mean percent were $1.82 \pm 0.6$ and $1.46 \pm 0.09$, respectively. Table (4).

The results revealed that natural fish samples were of higher ash content and the farmed fish samples. On the other hand the results also revealed that tilapia fish samples were also of a higher ash content than Mugil fish type.

These results attributed to the farmed fish fed on a diet of limited minerals, while the natural lived fish take a higher level of mineral from the natural conditions that causes increasing the level of ash in natural lived fish than the farmed fish.

Lower percentage values were reported by Erkan et al., (2010) where they, said that the normal row fish ash content percentage are $0.87 \%$. 
While the results agreed with those of Attouchi and sadok (2011) where they measured the proximate composition of both natural and farmed fish and found that the percent of moisture, protein fat and ash in fresh natural fish were $79.17 \pm 1.01,19.04 \pm 1.021 .53 \pm 0.27$, and $1.36 \pm 0.10$ respectively while the moisture, protein, fat and ash, percent in farmed fish were $75.10 \pm 1.03 \mathrm{~b}, \quad 19.95 \pm 0.91, \quad 4.82 \pm 0.44 \mathrm{~b}$, and $\quad 1.42 \pm 0.11$ respectively.

The previous data indicate that farmed fish is has more nutritional value than natural fish whereas both farmed fish types Tilapia nilotica and Mugil cephalus were higher in protein and fat content than natural fish and more studies are needed to improve the quality of farmed fish fat.

\section{REFERENCES}

- Abdelhamid, A.M.; Salem, M.F.I. and Tolan, A.E. (2005): Utilization of black seed meal (Nigella sativa) in Nile tilapia (Oreochromis niloticus) diets. J. Agric. Res. Tanta Univ., 31(3): 403419.

- Association of analytical chemists “AOAC" (2000): Official methods of analysis. 13 th Ed.,Horwitz, W. (Editor), Academic press, Washengton D.C.,USA.

- Attouchi, M., \& Sadok, S. (2010): The effect of powdered thyme sprinkling on quality changes of wild and farmed gilthead sea bream fillets stored in ice. Food Chemistry, 119, 1527-1534. 
- Aussanasuwannakul, A.; Kenney, P. B.; Brannan, R. G.; Slider, S. D.; Salem, M. and Yao, J. (2010): Relating Instrumental Texture, Determined by Variable-Blade and Allo-Kramer Shear Attachments, to Sensory Analysis of Rainbow Trout, Oncorhynchus mykiss, Fillets. J Food Sci. 2010 Sep;75(7):S365-74.

- Borges, P.; Oliveira, B.; Casal, S.; Dias, J.; Conceição, L. and Valente, L. M. (2009): Dietary lipid level affects growth performance and nutrient utilization of Senegalese sole (Solea senegalensis) juveniles. Br J Nutr. 2009 Oct;102 (7):1007-14. Epub 2009 Apr 27.

- Campos, C. A.; Gerschenson, L. N.; \& Flores, S. K. (2010). Development of edible films and coatings with antimicrobial activity. Food and Bioprocess Technology. i:10.1007/s11947- 010-0434-1. in press.

- El-Ebiary, E.H. and Zaki, M.A. (2003). Effect of supplementing active yeast to the diets on growth performance, nutrient utilization, whole body composition and blood constituents of mono-sex tilapia (O. nilaticus). Egypt. J. Aquat. Biol. \& Fish., 7(1): 127 - 139.

- Erkan, N.; Özden, Ö. and Selçuk, A. (2010): Effect of frying, grilling, and steaming on amino acid composition of marine fishes. $\mathrm{J}$ Med Food. 2010 Dec;13(6):1524-31. Epub 2010 Sep 27. 
- FAO Food and Agriculture Organization of United Nations (Fisheries and Aquaculture Department. Species Fact Sheets) (2007): Oreochromis niloticus (Linnaeus, 1758).

- Francesco, M. de., Parisi, G., Médale, F., Lupi, P., Kaushik, S.J., and Poli, B.M. (2004): Effect of long-term feeding with a plant protein mixture based diet on growth and body/fillet quality traits of large rainbow trout (Oncorhynchus mykiss). Aquaculture 236: 413429.

- Gine's, R., Valdimarsdottir, T., Sveinsdottir, K., Thorarensen, H., (2004): Effects of rearing temperature and strain on sensory characteristics, texture, colour and fat of Arctic charr (Salvelinus alpinus). Food Qual. Prefer.15, 177- 185.

- Grigorakis, K., Taylor, K.D.A., and Alexis, M.N. (2003): Organoleptic and volatile aroma compounds comparison of wild and cultured gilthead sea bream (Sparus aurata): sensory differences and possible chemical basis. Aquaculture 225: 109-119.

- Haard, N.F. (1992): Control of chemical composition and food quality attributes of cultured fish. Food Res. Int. 25, 289-307.

- Kaushik, S.J., Covés, D., Dutto, G., and Blanc, D. (2004): Almost total replacement of fish meal by plant protein source in the diet of a marine teleost, the European seabass, Dicentrarchus labrax. Aquaculture 230: 391-404. 
- Kristoffersen, S., Tobiassen, T., Esaiassen, M., Olsson, G. B., Godvik,L. A., Seppola, M. A., et al. (2006): Effects of pre-rigor filletingon quality aspects of Atlantic cod (Gadus morhua L.). AquacultureResearch, 37, 1556-1564.

- Morris, P.C. (2001): The Effects of Nutrition on the Composition of Farmed Fish, in Farmed Fish Quality, S.C Kestin and P.D. Warris (Eds.), p. 161-179. Fishing News Books, London.

- Nielsen, J., Hydlig, G., and Larsen, E. (2002): Eating quality of fishA review. J. Aquatic Food Prod. Technol. 11(3/4): 125-141.

- Pazos, M.; da Rocha, A. P.; Roepstorff, P. and Rogowska, A. (2011): Fish Proteins as Targets of Ferrous Catalysed Oxidation: Identification of Protein Carbonyls by Fluorescent-labelling on 2D-gels and MALDI-TOF/TOF. J Agric Food Chem. 2011 Jun 1. [Epub ahead of print] 


\section{الملخص العربي}

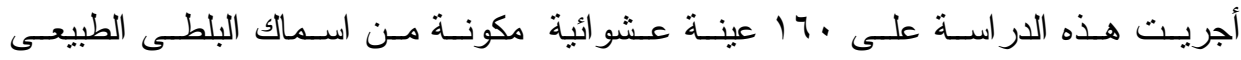

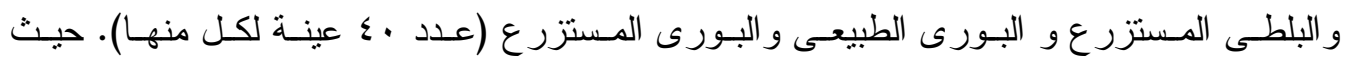
تـم تجميعهـا مـن ثـــى مـز ارع و بحيـرة البـرلس و القــوات المغذيـة لهـا بمحافظــة كفر الـشيخ خلال اثثى عشر شهر ا. حيث نم فحص العينات فحصا كيميائيا.

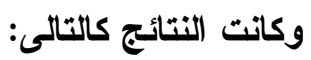

- أوضح التحليل الكيمبائى للحوم الأسماك أن أعلى مستوى للرطوبة وجد فى أسماك البلطى الطبيعى و البلطى المستزرع حيث كانت منوسطات الرطوبة 0.13 74.14 و 0.14 72.91 على التو الى بينما أقل مستوى للرطوبة لوحظ فى البورى الطبيعى ، البورى المستزرع وكانت منوسطات قيم الرطوبة 72.12 72.14 و 71.20_0.11 على التوالى ، بينما قيمة البروتينات تز اوحت بين مسنوى عالى فى البورى الطبيعى و البورى المستزر ع وكانت قيم البروتينات بهم 20.05_0.20 ، 18.9 18.17 بينما المستوى القليل من البروتينات فى البلطى العادى ، البلطى المستزرع حيث كانت نسبة البروتنيات بهم 18.51 18.18 ، $17.91 \pm 0.12$ على التوالى. كما أوضحت الدر اسة أن هناك فروقا معنوية و اضحة بين الاسماك عند مستوى معنوية ٪. - مستوى الدهون فى الاسماك تراوح بين معدل مرتفع فى البورى المستزرع و البورى الطبيعى حيث مستوى الدهون بهم $4.9 \pm 0.12$ ، 3.25 ومعدل منخفض فى أسماك البلطى المستزرع و البلطى الطبيعى و كان مستوى الدهون بهم $2.98 \pm 0.11 ،$ التو الى. بينما نسبة الاملاح فى الاسماك تز اوحت بين معدل مرتفع فى البلطى الطبيعى ، و البورى

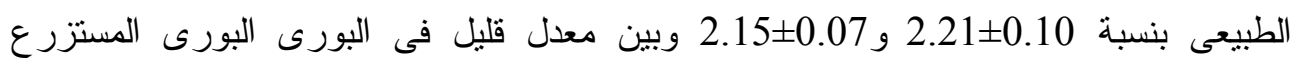

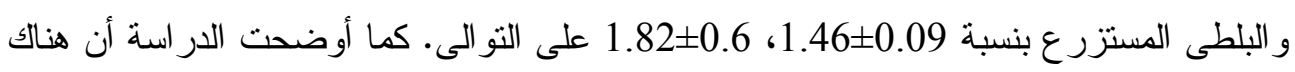
فروقا معنوية و اضحة بين الاسماك عند مستوى معنوية .

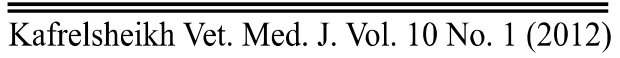

